\title{
Revision surgery for instrumentation failure after total en bloc spondylectomy: a retrospective case series
}

\author{
Kazuya Shinmura', Satoshi Kato', Satoru Demura ${ }^{1 *}$, Noriaki Yokogawa', Noritaka Yonezawa', Takaki Shimizu', \\ Norihiro Oku' ${ }^{1}$, Ryo Kitagawa ${ }^{1}$, Makoto Handa ${ }^{1}$, Ryohei Annen ${ }^{1}$, Hideki Murakami ${ }^{2}$ and Hiroyuki Tsuchiya $^{1}$
}

\begin{abstract}
Background: There have been several reports of instrumentation failure after three-column resections such as total en bloc spondylectomy (TES) for spinal tumors; however, clinical outcomes of revision surgery for instrumentation failure after TES are seldom reported. Therefore, this study assessed the clinical outcomes of revision surgery for instrumentation failure after TES.

Methods: This study employed a retrospective case series in a single center and included 61 patients with spinal tumors who underwent TES between 2010 and 2015 and were followed up for > 2 years. Instrumentation failure rate, back pain, neurological deterioration, ambulatory status, operation time, blood loss, complications, bone fusion after revision surgery, and re-instrumentation failure were assessed. Data were collected on back pain, neurological deterioration, ambulatory status, and management for patients with instrumentation failure, and we documented radiological bone fusion and re-instrumentation failure in cases followed up for $>2$ years after revision surgery.

Results: Of the 61 patients, 26 (42.6\%) experienced instrumentation failure at an average of 32 (range, 11-92) months after TES. Of these, 23 underwent revision surgery. The average operation time and intraoperative blood loss were $204 \mathrm{~min}$ and $97 \mathrm{ml}$, respectively. Including the six patients who were unable to walk after instrumentation failure, all patients were able to walk after revision surgery. Perioperative complications of reoperation were surgical site infection $(n=2)$ and delayed wound healing $(n=1)$. At the final follow-up, bone fusion was observed in all patients. No re-instrumentation failure was recorded.
\end{abstract}

Conclusion: Bone fusion was achieved by revision surgery using the posterior approach alone.

Keywords: Total en bloc spondylectomy, Instrumentation failure, Revision surgery, Cobalt chromium, Bone fusion, Liquid nitrogen

\footnotetext{
* Correspondence: msdemura@gmail.com

1 Department of Orthopedic Surgery, Graduate School of Medical Sciences, Kanazawa University, 13-1 Takara-machi, Kanazawa 920-0961, Japan

Full list of author information is available at the end of the article
}

(c) The Author(s). 2020 Open Access This article is licensed under a Creative Commons Attribution 4.0 International License, which permits use, sharing, adaptation, distribution and reproduction in any medium or format, as long as you give appropriate credit to the original author(s) and the source, provide a link to the Creative Commons licence, and indicate if changes were made. The images or other third party material in this article are included in the article's Creative Commons licence, unless indicated otherwise in a credit line to the material. If material is not included in the article's Creative Commons licence and your intended use is not permitted by statutory regulation or exceeds the permitted use, you will need to obtain permission directly from the copyright holder. To view a copy of this licence, visit http://creativecommons.org/licenses/by/4.0/. The Creative Commons Public Domain Dedication waiver (http://creativecommons.org/publicdomain/zero/1.0/) applies to the data made available in this article, unless otherwise stated in a credit line to the data. 


\section{Background}

Total en bloc spondylectomy (TES) was developed for complete surgical resection for spinal tumors [1, 2]. TES was reported to produce less local recurrence and better survival than piecemeal resection for primary tumors [3-7], aggressive benign tumors [1, 8], or metastatic spinal tumors $[1,9]$. TES involves complete resection of the affected vertebra(e) and surrounding musculoligamentous supportive tissues. The surgery presents a challenge for spinal reconstruction owing to the complete discontinuity in the spinal column. To restore spinal stability after resection, robust instrumentation and bone grafting are needed, with anterior column support [10-12]. Because TES is performed in patients with a relatively good prognosis [13], long-term stabilization of the spine is important. Failure of bone fusion can cause instrumentation failure, causing back pain, neurological deterioration, and decreased performance of activities of daily living (ADL) [13-18]. In most cases, revision surgery is required to improve spinal stability and symptoms.

Since 2010, instead of harvesting autografts from the ilium or fibula, the resected lamina and vertebral body from the TES are frozen in liquid nitrogen and used as grafted bone for spinal reconstruction. This technique has the following benefits: no pain at the bone harvest site, shortened operative time, decreased blood loss, and additional antitumor immune response [19]. In this procedure, the strategy of revision surgery is more important than that in the conventional procedure because the instrumentation failure rate may increase with a decreased bone fusion rate.

Despite the fact that several studies have examined instrumentation failure after TES [11-14], there are few published reports on revision surgery for instrumentation failure after TES. Therefore, the aims of this study were to determine the rate of instrumentation failure and to document clinical outcomes of revision surgery for instrumentation failure after TES with reconstruction using frozen autografts treated with liquid nitrogen.

\section{Methods}

\section{Study population}

This retrospective study was approved by our institutional review board, and informed consent was obtained from all patients. Between 2010 and 2015, 114 patients with primary or metastatic spinal tumors underwent TES at our institute. Of these, 33 patients died within 2 years, and 20 patients were lost to follow-up. Finally, 61 patients $(53.5 \%)$ who could be followed up for $>2$ years after TES were included and comprised 35 men and 26 women, with a mean age of 52.6 (range 14-73) years. The mean follow-up period was 60 (range 24-101) months. Of the 61 patients, 10 had primary malignant tumors, 10 had primary aggressive benign tumors, and 41 had metastatic tumors. In 41 patients with metastatic disease, metastases were diagnosed as having oligometastatic cancer. The thoracic, thoracolumbar, and lumbar spines were affected in 27, 27, and seven patients, respectively.

\section{Surgical procedures}

Primary surgery (TES) consisted of en bloc laminectomy after transpedicular osteotomy, subsequent en bloc corpectomy, and spinal reconstruction $[8,20]$. After en bloc laminectomy, two-above and two-below segmental fixations were performed in all patients. Two rods were used in all patients. Titanium alloy rods (diameter: $5.5 \mathrm{~mm}$ ) were used in 59 patients. Cobalt chromium rods (diameter: $6.0 \mathrm{~mm}$ ) were used in two patients. No hooks or wires were used. After posterior instrumentation, anterior reconstruction was performed using a titanium mesh cage (MOSS-Miami; DePuy Motech, Warsaw, IN, USA) filled with frozen autografts treated with liquid nitrogen. To increase spinal stability, the posterior instrumentation was adjusted to slightly compress the inserted vertebral cage. Finally, at least two transverse connectors were applied. In all cases, a rigid spinal brace was used for a postoperative period of 3 months, followed by a soft brace for another 3 months.

Revision surgery after instrumentation failure was performed via the posterior approach alone in all cases. Broken rods and broken or loosening pedicle screws were replaced. In some patients, segmental fixation was extended to increase stability. In most patients, a fresh autologous bone strut graft harvested from the iliac crest was placed on the scar tissue of the resected vertebral area to form a bridge between the adjacent laminae (Fig. 1a, b). In some patients, additional fresh autologous bone grafts were placed around the cage. The posterior instrumentation was adjusted to slightly compress the inserted vertebral cage. To increase stability, four rod fixations were applied in most cases (Fig. 1c). No patients had cage replacement via the anterior approach. In all cases, a rigid spinal brace was used for a postoperative period of 3 months, followed by a soft brace for another 3 months.

\section{Evaluation}

Instrumentation failure was determined based on followup plain radiographs. In cases of instrumentation failure, computed tomography (CT) was performed to determine the details of instrumentation failure. Back pain, neurological deterioration, ambulatory status, and management (conservative or revision surgery) were recorded. Operative time, intraoperative blood loss, and complications of the revision surgery were documented. Finally, we evaluated the extent of radiological bone 

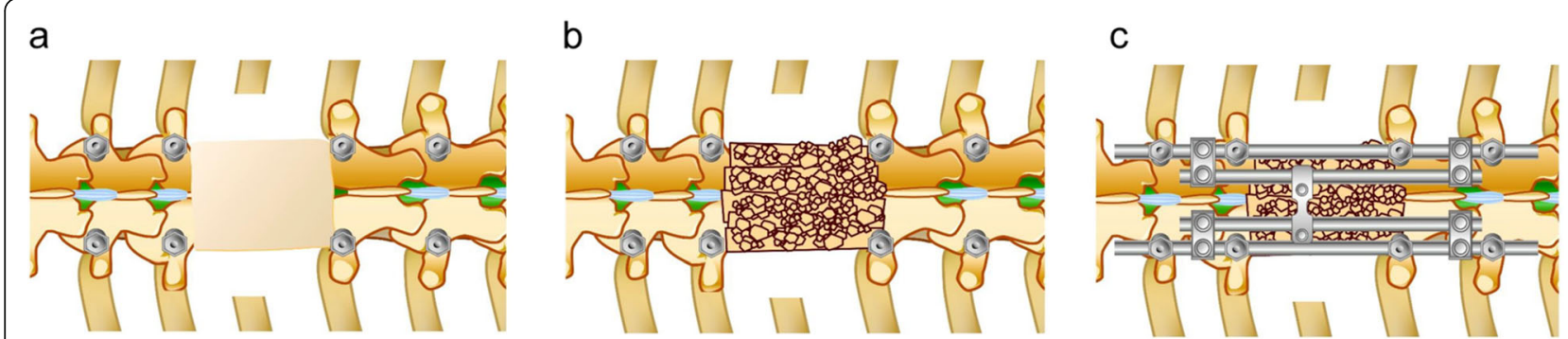

Fig. 1 Schema of revision surgery after instrumentation failure. a The scar tissue of the resected vertebral area and the adjacent laminae are exposed. b Fresh autologous bone strut graft harvested from the iliac crest is placed on the scar tissue of the resected vertebral area to form a bridge between the adjacent laminae. c To increase stability, additional rods are applied

fusion using multiplanar reconstruction $\mathrm{CT}$ in cases of re-instrumentation failure that could be followed up for $>2$ years after revision surgery. The graft bone in the cage was continuous with the upper and lower adjacent vertebral bodies, and a cage filled with bone tissue was considered bone fusion within the cage.

\section{Results}

Of the 61 patients, 26 (42.6\%) experienced instrumentation failure at an average of 32 (range, 11-92) months after TES. The mean body mass index of the patients who experienced instrumentation failure was 23.4 (range, 16.4-32.3). Of the 26 patients who experienced instrumentation failure, 4 (15.3\%) underwent radiation therapy for spinal tumors before TES. Ten patients had primary tumors, comprising giant cell tumor in 3 patients, chondrosarcoma in 1, epithelioid sarcoma in 1, liposarcoma in 1, Ewing's sarcoma in 1, synovial sarcoma in 1 , chordoma in 1 and aggressive hemangioma in 1 . Sixteen patients had metastatic tumors from renal cell carcinoma in 4 patients, breast cancer in 3, thyroid cancer in 2, lung cancer in 2, hepatocellular carcinoma in 1 , esophageal cancer in 1, parotid cancer in 1, leiomyosarcoma in 1 , unknown primary squamous cell carcinoma in 1. Rod breakage was observed in 20 patients, screw breakage in two patients, rod and cage breakage in two patients, cage breakage in one patient, and screw and cage breakage in one patient. However, no evidence of local recurrence was found at the surgical site throughout the follow-up period in any patient. Of the 26 patients, 19 (73.1\%) experienced back pain, 8 (30.8\%) had lower-extremity neurological deterioration, and 6 (23.1\%) were unable to walk because of these symptoms (Table 1). Of the 26 patients, 23 underwent revision surgery and three did not undergo revision surgery. In patients without revision surgery, one patient (patient 26; Table 1) with an asymptomatic rod breakage died from cancer 1 year after instrumentation failure. Patients with asymptomatic cage and screw breakage (patients 24 and 25; Table 1) survived for 1 year and 3 years, respectively. Neither experienced advanced spinal instability nor related symptoms. Revision surgery was performed with posterior instrumentation replacement in all 23 patients, posterior bone grafting in 21 patients, and additional bone grafting around the cage in three patients. To increase stability, the procedure was extended by three segmental fixations above and below in three patients, two segmental fixations above and below in one patient, and two segmental fixations above and four segmental fixations below in two patients. All of the six patients with extended fixation had screw loosening. In the remaining cases without screw loosening, instrumentation was not extended. Two rods were used in four patients, three rods were used in one patient, and four rods were used in 18 patients. Titanium alloy rods (diameter: $5.5 \mathrm{~mm}$ ) and cobalt chromium rods (diameter: $6.0 \mathrm{~mm}$ ) were used in 4 and 20 patients, respectively. The average operative time and intraoperative blood loss were $207 \pm 45$ (range, 121-287) $\mathrm{min}$ and $93 \pm 81$ (range, 20-270) $\mathrm{ml}$, respectively. Intraoperative findings via a posterior approach did not reveal any obvious pseudoarthroses in the patients because the scar tissue covered the anterior column where the pseudoarthroses existed, but mild metallosis at the rod fracture site was observed in nine patients. All patients, including the six patients who were unable to walk due to symptomatic instrumentation failure, maintained or recovered their ambulation function after revision surgery. Perioperative complications of revision surgery were superficial surgical site infection in two patients and delayed wound healing in one patient. They were successfully treated with conservative therapies using antibiotics and basic fibroblast growth factor spray.

Eighteen patients could be followed up for $>2$ years after revision surgery (average follow-up period: 41 months) by radiological evaluation. At the last follow-up, bone fusion was achieved within the anterior cage and at the posterior bone graft in 11 patients, within the anterior cage in two patients, and at the posterior bone graft in five patients. There was no re-instrumentation failure after revision surgery (Table 2). 
Table 1 Details of patients who experienced instrumentation failure

\begin{tabular}{|c|c|c|c|c|c|c|c|c|c|c|c|c|}
\hline No. & Age & Sex & BMI & Type of tumor & RT & $\begin{array}{l}\text { Resection } \\
\text { level }\end{array}$ & $\begin{array}{l}\text { Broken parts } \\
\text { in instrumentation } \\
\text { failure }\end{array}$ & $\begin{array}{l}\text { Duration } \\
\text { after TES } \\
(\mathrm{mo})\end{array}$ & Back pain & $\begin{array}{l}\text { Neurological } \\
\text { deterioration }\end{array}$ & Ambulatory & $\begin{array}{l}\text { Revision } \\
\text { surgery }\end{array}$ \\
\hline 1 & 39 & $M$ & 24.0 & thyroid cancer & no & T4 & 2 rods & 42 & + & - & yes & yes \\
\hline 2 & 63 & $\mathrm{~F}$ & 21.0 & thyroid cancer & no & $\mathrm{T} 4,5,6$ & $1 \mathrm{rod}$ & 74 & + & - & yes & yes \\
\hline 3 & 57 & $\mathrm{~F}$ & 22.3 & parotid cancer & no & $T 5,6$ & 2 rods & 92 & + & - & yes & yes \\
\hline 4 & 59 & $\mathrm{~F}$ & 22.6 & breast cancer & yes & $\mathrm{T} 6,7$ & 2 rods & 24 & - & $\begin{array}{l}\text { bilateral leg } \\
\text { weakness }\end{array}$ & no & yes \\
\hline 5 & 68 & M & 22.4 & $\begin{array}{l}\text { hepatocellular } \\
\text { carcinoma }\end{array}$ & yes & $\mathrm{T7}$ & 2 rods & 51 & - & $\begin{array}{l}\text { bilateral leg } \\
\text { weakness }\end{array}$ & yes & yes \\
\hline 6 & 24 & M & 22.0 & leiomyosarcoma & no & $\mathrm{T} 7,8$ & $1 \mathrm{rod}$ & 29 & + & - & yes & yes \\
\hline 7 & 41 & $\mathrm{~F}$ & 16.4 & synovial sarcoma & yes & $\mathrm{T} 8,9$ & 2 rods & 37 & + & - & yes & yes \\
\hline 8 & 68 & M & 23.2 & renal cell carcinoma & no & $\mathrm{T} 8,9$ & 2 rods & 18 & + & - & yes & yes \\
\hline 9 & 59 & M & 24.2 & renal cell carcinoma & no & $\mathrm{T} 8,9,10$ & 2 rods & 11 & + & - & no & yes \\
\hline 10 & 59 & M & 24.3 & lung cancer & no & $\mathrm{T} 8,9,10$ & 2 rods and cage & 25 & + & $\begin{array}{l}\text { bilateral leg } \\
\text { weakness }\end{array}$ & no & yes \\
\hline 11 & 66 & $\mathrm{~F}$ & 18.4 & esophageal cancer & no & T9 & $1 \mathrm{rod}$ & 17 & + & - & yes & yes \\
\hline 12 & 26 & M & 27.0 & epithelioid sarcoma & no & $\mathrm{T} 10$ & 2 rods & 34 & + & $\begin{array}{l}\text { bilateral leg } \\
\text { paresthesia }\end{array}$ & yes & yes \\
\hline 13 & 40 & M & 26.3 & liposarcoma & no & $\mathrm{T} 10$ & $1 \mathrm{rod}$ & 38 & - & - & yes & yes \\
\hline 14 & 45 & M & 23.6 & chondrosarcoma & no & $\mathrm{T} 10$ & $1 \mathrm{rod}$ & 32 & + & - & yes & yes \\
\hline 15 & 70 & M & 25.2 & unknown & no & $\mathrm{T} 10,11$ & 2 rods & 11 & + & - & no & yes \\
\hline 16 & 14 & M & 24.3 & Ewing's sarcoma & no & $\mathrm{T} 12$ & 2 screws & 22 & - & - & yes & yes \\
\hline 17 & 48 & M & 28.4 & renal cell carcinoma & no & T12, L1 & 2 rods & 19 & + & $\begin{array}{l}\text { bilateral leg } \\
\text { paresthesia }\end{array}$ & yes & yes \\
\hline 18 & 66 & $\mathrm{~F}$ & 22.4 & breast cancer & no & L1 & $1 \mathrm{rod}$ & 18 & + & - & yes & yes \\
\hline 19 & 16 & M & 22.8 & chordoma & no & $\mathrm{L} 1,2$ & 2 rods and cage & 21 & + & - & yes & yes \\
\hline 20 & 64 & M & 19.9 & $\begin{array}{l}\text { aggressive } \\
\text { hemangioma }\end{array}$ & no & L2 & $1 \mathrm{rod}$ & 23 & + & - & yes & yes \\
\hline 21 & 49 & $\mathrm{~F}$ & 30.9 & giant cell tumor & no & $\llcorner 4,5$ & 2 rods & 39 & + & $\begin{array}{l}\text { bilateral leg } \\
\text { paresthesia }\end{array}$ & no & yes \\
\hline 22 & 25 & $\mathrm{~F}$ & 17.2 & giant cell tumor & no & $\llcorner 4$ & cage and 1 screw & 31 & + & $\begin{array}{l}\text { bilateral leg } \\
\text { paresthesia }\end{array}$ & yes & yes \\
\hline 23 & 50 & M & 32.3 & lung cancer & no & L5 & 2 rods & 24 & + & $\begin{array}{l}\text { bilateral leg } \\
\text { pain }\end{array}$ & no & yes \\
\hline 24 & 21 & $\mathrm{~F}$ & 24.3 & giant cell tumor & no & $\mathrm{T} 11$ & cage & 24 & - & - & yes & no \\
\hline 25 & 41 & $\mathrm{~F}$ & 22.2 & breast cancer & no & L3 & 2 screws & 35 & - & - & yes & no \\
\hline 26 & 70 & M & 20.8 & renal cell carcinoma & yes & L3 & $1 \mathrm{rod}$ & 30 & - & - & yes & no \\
\hline
\end{tabular}

$B M I$ body mass index, $R T$ radiation therapy

\section{Illustrative case (case 18)}

The patient was a 66-year-old woman with a solitary spinal metastasis from breast cancer. She underwent TES of L1 with two-above and two-below segmental fixation using two titanium alloy rods. At 18 months after TES, radiography revealed an increased local kyphosis angle between T12 and L2. Breakage of the left rod was noted on CT. Revision surgery was performed using a single posterior approach. The rod on the left side was broken at the proximal level of the L2 pedicle screw. Transverse connectors and bilateral rods were removed, and the loosening pedicle screw at the left T11 level was replaced. Spinal fixation was performed using four cobalt chromium rods (diameter: 6.0 $\mathrm{mm}$ ). An autologous strut bone graft was placed on the scar tissue of the resected L1 lamina area and the adjacent T12 and L2 laminae. The posterior instrumentation was adjusted to slightly compress the inserted vertebral cage. No perioperative complications occurred. The patient reacquired ambulatory function, without aid, 1 week after the revision surgery. At 42 months after the revision surgery, bone fusion within the cage and at the posterior bone graft was observed on CT (Fig. 2). 


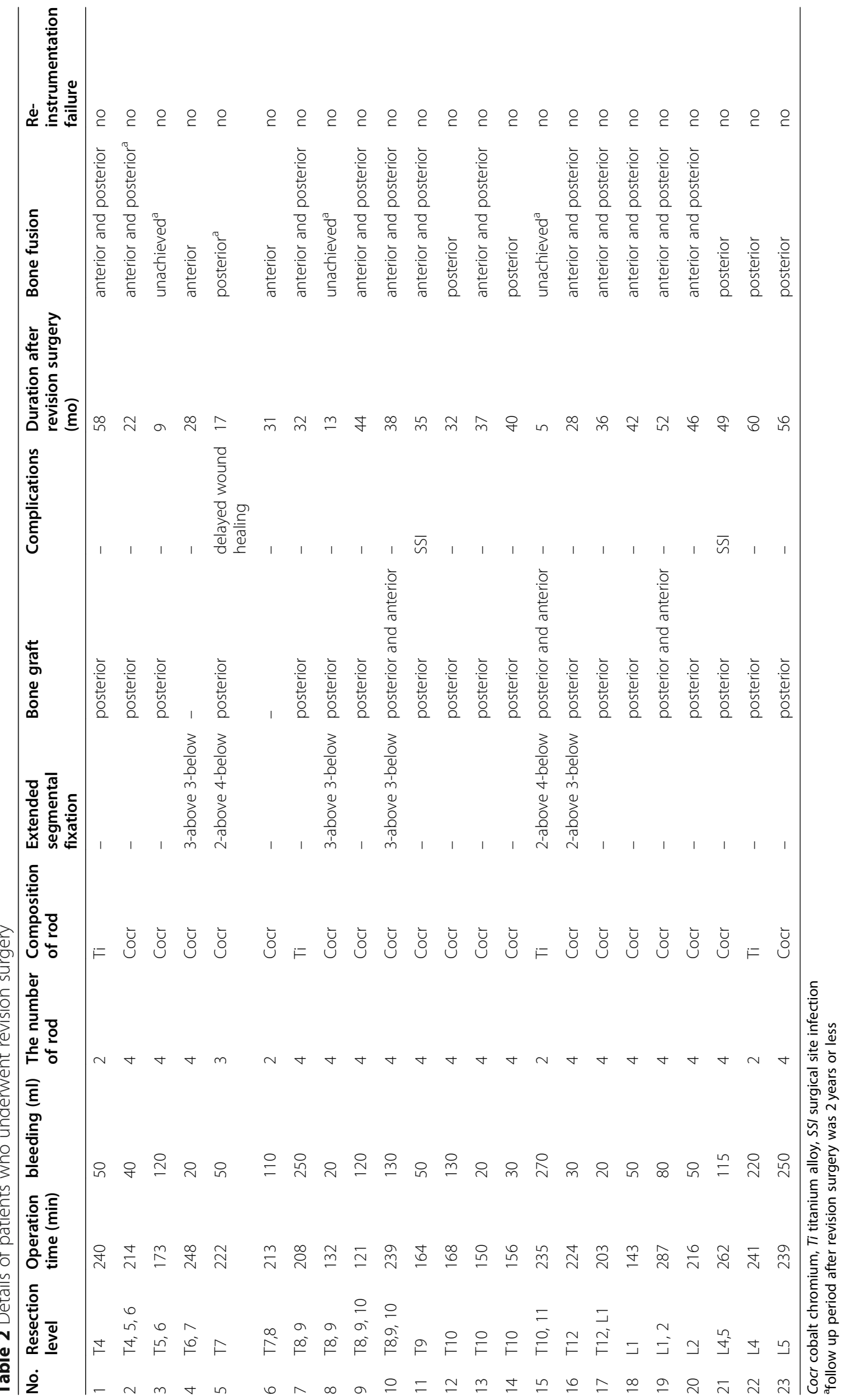




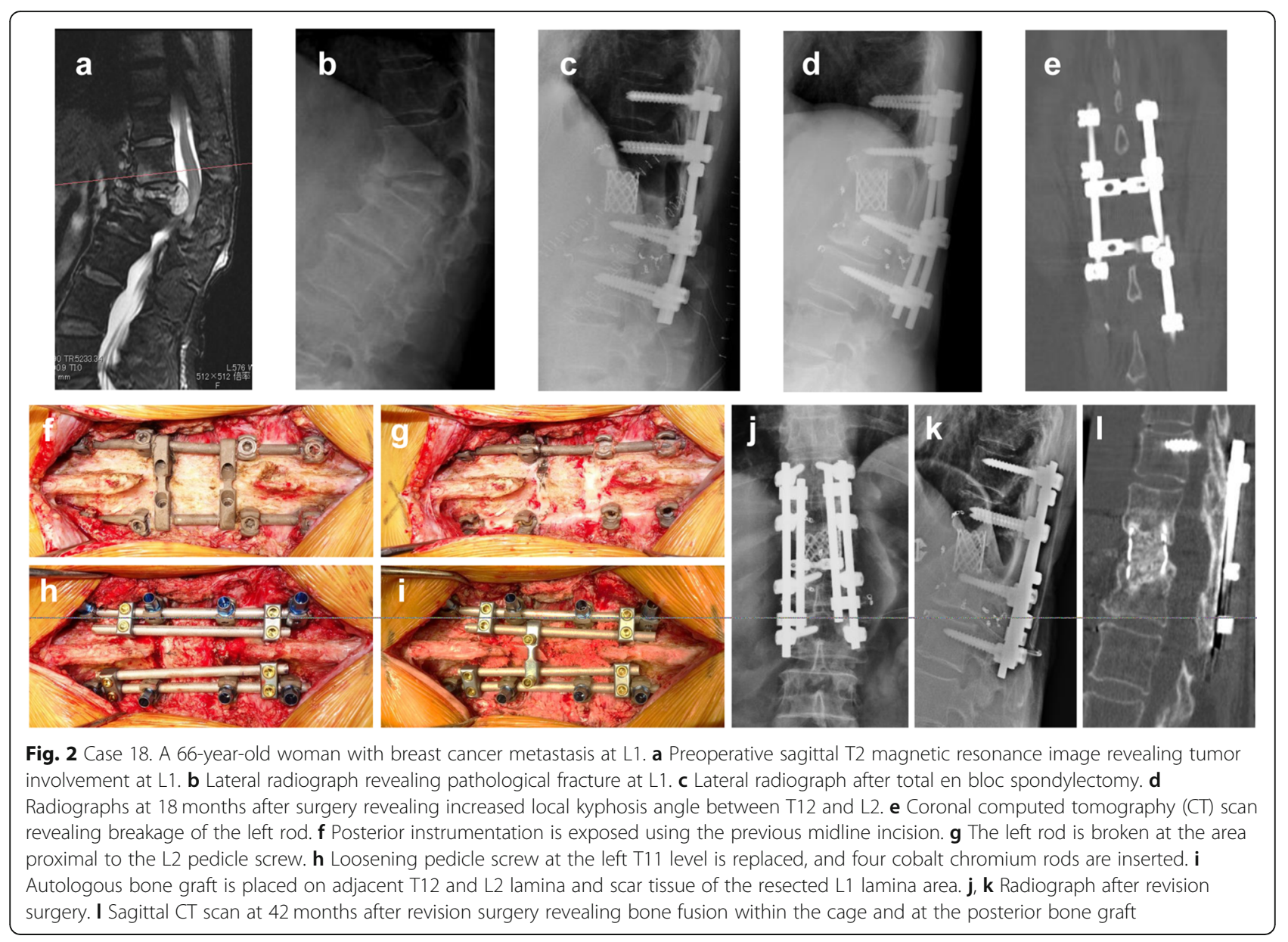

\section{Discussion}

We reported the instrumentation failure rate of patients with instrumentation failure after TES with reconstruction using frozen autografts treated with liquid nitrogen. Revision surgery was performed using the posterior approach alone. Bone fusion was achieved, and there was no re-instrumentation failure in any patient at the follow-up period $>2$ years.

With continuing advances in cancer therapy, acceptable long-term prognosis can be expected even in patients with metastatic spinal tumors [21-24]. In TES, en bloc resection of a tumor-bearing vertebra can be curative, leading to longer-term survival, and achieving bone fusion of the reconstructed vertebral body is essential [25]. However, instrumentation failure caused by unsuccessful bone fusion is not a rare complication. Park et al. [10] reported that $12(37.5 \%)$ of 32 patients experienced rod breakage at an average of 29.2 (range, 8-93) months after TES. Sciubba et al. [14] reported instrumentation failure in 9 (39.1\%) of 23 patients who underwent lumbar-spine TES. Matsumoto et al. [12] reported instrumentation failure in $6(40 \%)$ of 15 patients who underwent TES. In our study, instrumentation failure following the TES procedure was identified in 26 (42.6\%) of 61 patients at an average of 32 (range, 11-92) months after TES, which was comparable to that of other studies.

The previously reported incidence rate of instrumentation failure after TES using the same reconstruction method as ours (except using fresh autologous bone for bone grafting) was $17.0 \%(8 / 47)$ [11]; in the present study, the instrumentation failure rate after TES using frozen bone was $42.6 \%(26 / 61)$. It was reported that bone formation tended to be delayed when frozen bone autografts were used compared with fresh bone autografts [25]; therefore, the instrumentation failure rate in the present study was higher than that previously reported [11]. Although bone fusion was delayed, complete bone fusion within the cage was obtained in the TES model canine using frozen bone [25]. The instrumentation failure rate following the first procedure was higher in the present study; however, stability was maintained for a long time in $35(57.4 \%)$ of 61 patients. Considering the advantages of using liquid nitrogen-treated bone, we continue using frozen bone autografts in spinal reconstruction during TES. To decrease the incidence of 
instrumentation failure, we recently began using a more robust cage and cobalt chrome rods to create a stiffer construct of the operated spine and having additional bone graft around the cage to facilitate bone fusion.

In the present study, back pain and neurological deterioration caused by instrumentation failure developed in $19(76.1 \%)$ and 8 (30.8\%) patients, respectively. Matsumoto et al. [12] reported that all $6(100 \%)$ patients experienced back pain and 1 (16.7\%) experienced neurological deterioration at the time of instrumentation failure. Park et al. [10] reported that back pain developed in 7 (58.3\%) patients, and no patients had neurological deterioration at the time of instrumentation failure. These findings suggest that most patients with instrumentation failure experienced significant clinical symptoms. Revision surgery is necessary to prevent decreased ADL performance among symptomatic patients with instrumentation failure.

Instrumentation failure is caused by delayed union between the cage and the vertebral body [11], and revision surgery is performed to achieve robust restabilization and bone fusion. In the present study, we performed robust restabilization in most patients by replacing titanium rods with cobalt chromium rods and by increasing the number of rods. We also performed bone grafting at the posterior aspect of the spine. During the primary surgery, bone grafting at the posterior element was difficult because there was no bed for bone grafting at the level of the resected vertebra. Moreover, because the space was covered with scar tissue, bone grafting was straightforward and secured during the revision surgery.

In the present study, $13(72.2 \%)$ of 18 patients with > 2 years of follow-up after revision surgery achieved bone fusion within the cage, but the remaining 5 (27.8\%) did not achieve bone fusion; nevertheless, bone resorption within the cage improved. We believe that robust restabilization of the posterior instrumentation increased the stability of the spine, which facilitated bone fusion within the cage. In addition, bone fusion at the posterior aspect of the spine, which could not be applied in the primary surgery without the scar tissue of the resected vertebral area, was achieved earlier than that within the cage in cases where posterior bone grafting was performed. We believe that attaining bone fusion at the posterior aspect further increased the stability of the spine and favored bone fusion within the cage. This finding indicates that replacement of the cage using the anterior approach is unnecessary when the cage is restabilized using a stiffer construction by exchange and supplement of posterior instruments. Our recommended revision procedure is to perform posterior restabilization with three or four cobalt chromium rods and posterior bone grafting. In cases with a severely damaged cage (not observed in this study cohort), cage replacement using the anterior approach should be considered.
This study has some limitations. The small and heterogenous cohort with several tumor histologies and adjuvant therapies and the retrospective manner of data collection can introduce bias and errors. This retrospective study included various reconstruction procedures (e, $\mathrm{g}$, the material and number of rods in revision surgery) differed depending on the time of surgery. The followup time was limited as well. Longer follow-up is required to determine the accurate incidence of instrumentation failure after revision surgery. Although all patients were diagnosed as having oligometastatic cancer in the present study, the indications for TES remain controversial because less invasive surgeries (e.g. separation surgery) have shown significant results recently. Despite these limitations, this study demonstrated the rate of instrumentation failure after TES with reconstruction using frozen autografts treated by liquid nitrogen and described a relatively simple and effective strategy for revision surgery and its favorable outcomes. The results obtained from this study will contribute to revision surgery for instrumentation failure after TES.

\section{Conclusions}

In patients with instrumentation failure after TES, posterior instrumentation replacement and posterior bone grafting were performed during revision surgery. In this study, bone fusion was observed in all patients with $>2$ years of follow-up after revision surgery, and no reinstrumentation failure was observed during follow-up. Our findings suggest that bone fusion can be achieved by revision surgery using the posterior approach.

\section{Abbreviations \\ ADL: Activities of daily living; CT: Computed tomography; TES: Total en bloc spondylectomy}

\section{Acknowledgments \\ Not applicable.}

Authors' contributions

Research conception and design: KS, SK, SD. Data collection: KS, N Yokogawa, N Yonezawa, TS, NO, RK, MH, RA. Interpretation of data: KS, SK, SD, N Yokogawa. Drafting the manuscript: KS. Manuscript review: SK, SD, HM, HT. Study supervision: HM, HT. Approval of the final manuscript: all the abovelisted authors.

\section{Funding}

No funding was received for this study.

Availability of data and materials

The datasets generated during and/or analyzed during the current study are available from the corresponding author on reasonable request.

\section{Ethics approval and consent to participate}

All procedures performed in studies involving human participants were in accordance with the ethical standards of the institutional and/or national research committee and with the 1964 Helsinki Declaration and its later amendments or comparable ethical standards. The study was approved by the Ethics Committee of the Graduate School of Medical Sciences, Kanazawa University. The written informed consent was obtained from all individual participants included in the study. 


\section{Consent for publication}

Patients signed informed consent regarding publishing their data and photographs.

\section{Competing interests}

The authors declare that they have no conflict of interest.

\section{Author details}

'Department of Orthopedic Surgery, Graduate School of Medical Sciences, Kanazawa University, 13-1 Takara-machi, Kanazawa 920-0961, Japan.

${ }^{2}$ Department of Orthopedic Surgery, Nagoya City University Graduate School of Medical Sciences, Nagoya, Japan.

Received: 27 April 2020 Accepted: 31 August 2020

Published online: 02 September 2020

\section{References}

1. Tomita K, Kawahara N, Baba H, Tsuchiya H, Nagata S, Toribatake Y. Total en bloc spondylectomy for solitary spinal metastases. Int Orthop. 1994;18:2918.

2. Tomita K, Kawahara N, Baba H, Tsuchiya H, Fujita T, Toribatake Y. Total en bloc spondylectomy: a new surgical technique for primary malignant vertebral tumors. Spine (Phila Pa 1976). 1997;22:324-33.

3. Schwab J, Gasbarrini A, Bandiera S, Boriani L, Amendola L, Picci P, et al. Osteosarcoma of the mobile spine. Spine. 2012;37:E381-6.

4. Kato S, Murakami H, Demura S, Yoshioka K, Kawahara N, Tomita K, et al. More than 10-year follow-up after total en bloc spondylectomy for spinal tumors. Ann Surg Oncol. 2014;21:1330-6. https://doi.org/10.1245/s10434013-3333-7.

5. Amendola L, Cappuccio M, De lure F, Bandiera S, Gasbarrini A, Boriani S. En bloc resections for primary spinal tumors in 20 years of experience: effectiveness and safety. Spine J. 2014;14:2608-17. https://doi.org/10.1016/j. spinee.2014.02.030.

6. Schoenfeld AJ, Hornicek FJ, Pedlow FX, Kobayashi W, Raskin KA, Springfield D, et al. Chondrosarcoma of the mobile spine: a review of 21 cases treated at a single center. Spine. 2012;37:119-26. https://doi.org/10.1097/BRS. Ob013e31823d2143.

7. Shimizu T, Murakami H, Demura S, Kato S, Yoshioka K, Yokogawa N, et al. Total en bloc spondylectomy for primary tumors of the lumbar spine. Medicine. 2018;97:e12366. https://doi.org/10.1097/MD.0000000000012366.

8. Yokogawa N, Murakami H, Demura S, Kato S, Yoshioka K, Shimizu T, et al. Total spondylectomy for Enneking stage III giant cell tumor of the mobile spine. Eur Spine J. 2018;27:3084-91. https://doi.org/10.1007/s00586-0185761-3.

9. Demura S, Kawahara N, Murakami H, Abdel-Wanis ME, Kato S, Yoshioka K, et al. Total en bloc spondylectomy for spinal metastases in thyroid carcinoma. J Neurosurg Spine. 2011;14:172-6. https://doi.org/10.3171/2010.9. SPINE09878.

10. Park SJ, Lee CS, Chang BS, Kim YH, Kim H, Kim SI, Chang SY. Korean Spine Tumor Study Group Rod fracture and related factors after total en bloc spondylectomy. Spine J. 2019;19:1613-9. https://doi.org/10.1016/j.spinee. 2019.04.018.

11. Yoshioka K, Murakami H, Demura S, Kato S, Yokogawa N, Kawahara N, et al. Risk factors of instrumentation failure after multilevel total en bloc spondylectomy. Spine Surg Relat Res. 2017;1:31-9. https://doi.org/10.22603/ ssrr.1.2016-0005.

12. Matsumoto M, Watanabe K, Tsuji T, Ishii K, Nakamura M, Chiba K, et al. Late instrumentation failure after total en bloc spondylectomy. J Neurosurg Spine. 2011;15:320-7. https://doi.org/10.3171/2011.5.SPINE10813.

13. Tomita K, Kawahara N, Kobayashi T, Yoshida A, Murakami H, Akamaru T. Surgical strategy for spinal metastases. Spine. 2001;26:298-306.

14. Sciubba DM, De la Garza RR, Goodwin CR, Xu R, Bydon A, Witham TF, et al. Total en bloc spondylectomy for locally aggressive and primary malignant tumors of the lumbar spine. Eur Spine J. 2016;25:4080-7. https://doi.org/10. 1007/s00586-016-4641-y.

15. Kawahara N, Tomita K, Murakami H, Demura S, Yoshioka K, Kato S. Total en bloc spondylectomy of the lower lumbar spine: a surgical techniques of combined posterior-anterior approach. Spine. 2011;36:74-82. https://doi.org/ 10.1097/BRS.0b013e3181cded6c.

16. Disch AC, Schaser KD, Melcher I, Feraboli F, Schmoelz W, Druschel C, et al. Oncosurgical results of multilevel thoracolumbar en-bloc spondylectomy and reconstruction with a carbon composite vertebral body replacement system. Spine (Phila Pa 1976). 2011;36:E647-55. https://doi.org/10.1097/BRS. Ob013e3181f8cb4e.

17. Luzzati AD, Shah S, Gagliano F, Perrucchini G, Scotto G, Alloisio M. Multilevel en bloc spondylectomy for tumors of the thoracic and lumbar spine is challenging but rewarding. Clin Orthop Relat Res. 2015;473:858-67. https:// doi.org/10.1007/s11999-014-3578-x.

18. Barton C, Noshchenko A, Patel V, Cain C, Kleck C, Burger E. Risk factors for rod fracture after posterior correction of adult spinal deformity with osteotomy: a retrospective case-series. Scoliosis. 2015;10:30. https://doi.org/ 10.1186/s13013-015-0056-5.

19. Murakami H, Kato S, Demura S, Yoshioka K, et al. Novel reconstruction technique using a frozen tumor-bearing vertebra from a total en bloc sponydylectomy for spinal tumors. Orthopedics. 2013;36:605-7. https://doi. org/10.3928/01477447-20130724-04.

20. Kawahara N, Tomita K, Murakami H, Demura S. Total en bloc spondylectomy for spinal tumors: surgical techniques and related basic background. Orthop Clin North Am. 2009;40:47-63. https://doi.org/10.1016/j.ocl.2008.09.004.

21. Elder BD, Sankey EW, Goodwin CR, Kosztowski TA, Lo SF, Bydon A, et al. Surgical outcomes in patients with high spinal instability neoplasm score secondary to spinal giant cell tumors. Global Spine J. 2016;6:21-8. https:// doi.org/10.1055/s-0035-1555657.

22. Garofalo F, di Summa PG, Christoforidis D, Pracht M, Laudato P, Cherix S, et al. Multidisciplinary approach of lumbosacralchordoma: from oncological treatment to reconstructive surgery. J Surg Oncol. 2015;112:544-54. https:// doi.org/10.1002/jso.24026

23. Greco C, Pares O, Pimentel N, Moser E, Louro V, Morales X, et al. Spinal metastases: from conventional fractionated radiotherapy to single-dose SBRT. Rep Pract Oncol Radiother. 2015;20:454-63. https://doi.org/10.1016/j. rpor.2015.03.004.

24. Joaquim AF, Powers A, Laufer I, Bilsky MH. An update in the management of spinal metastases. Arq Neuropsiquiatr. 2015;73:795-802. https://doi.org/ 10.1590/0004-282X20150099.

25. Shinmura K, Murakami H, Demura S, Kato S, Yoshioka K, Hayashi H, et al. A histological examination of spinal reconstruction using a frozen bone autograft. PLoS One. 2018;13:e0191679. https://doi.org/10.1371/journal.pone. 0191679.

\section{Publisher's Note}

Springer Nature remains neutral with regard to jurisdictional claims in published maps and institutional affiliations.

Ready to submit your research? Choose BMC and benefit from:

- fast, convenient online submission

- thorough peer review by experienced researchers in your field

- rapid publication on acceptance

- support for research data, including large and complex data types

- gold Open Access which fosters wider collaboration and increased citations

- maximum visibility for your research: over $100 \mathrm{M}$ website views per year

At BMC, research is always in progress.

Learn more biomedcentral.com/submissions 